Journal Universitas Muhammadiyah Gresik Engineering, Social Science, and Health International Conference (UMGESHIC)

UMGCINMATIC : $1^{\text {st }}$ Rethinking Education during Covid-19 Era: Challange and Innovation

\title{
THE EFFECT OF LIQUIDITY AND ASSETS STRUCTURE ON CAPITAL STRUCTURE WITH COMPANY SIZE AS A CONTROL VARIABLE ON MANUFACTURING COMPANIES IN THE INDONESIA STOCK EXCHANGE
}

\author{
Author \\ Anggie Nur Safitri A. S' , Mu'minatus Sholichah ${ }^{2}$ \\ Universitas Muhammadiyah Gresik ${ }^{1}$, Universitas Muhammadiyah Gresik ${ }^{2}$ \\ anggienursafitri.ba.03@gmail.com ${ }^{1}$, mi2ensholichah@yahoo.com²
}

\begin{abstract}
The purpose of this study was to examine whether or not the influence of the independent variables of liquidity and asset structure on capital structure with firm size as a control variable. The object of this research is a manufacturing company listed on the Indonesia Stock Exchange (IDX) which is engaged in the consumer goods industry sector for the period 2017 to 2020 . Research data collection is carried out by using documentation techniques on the sample company financial statement items. By using purposive sampling, the final sample size was 35 company. The research hypotheses were tested using multiple linear regression analysis Hypothesis test results. The results showed that the independent variable liquidity had a significant negative effect on capital structure. The independent variable of asset structure has no significant positive effect on capital structure. And the control variable firm size has no significant positive effect on capital structure.
\end{abstract}

Keywords: Liquidity, Asset Structure, Capital Structure, Firm Size, Control Variables

\section{INTRODUCTION}

Company activities are an inseparable part of the financial function. The financial function is one of the important functions for the company in carrying out the company's activities. In managing the financial function, one element that needs to be considered is how much the company is able to meet the needs of funds that will be used for its operations and developing its business. This funding can come from own funds, share capital or debt, both short-term debt and long-term debt.

Expenditure and investment plans are important decisions for financial managers because they are related to fundraising activities. One way to find funds or capital for companies is through the capital market because in the capital market it is possible for companies to issue securities or securities (Kartika, 2016). However, the company's decision to use its source of funds produces a different impact for each company. Financial management must be able to balance 
the capital structure so that short-term and long-term needs can be met and financed properly from the company's internal and external funding sources.

The company's capital structure is one of the fundamental factors in the company's operations. So it can be understood that the capital structure is a description of the form of the company's financial proportions, namely between owned capital which comes from long-term debt and own capital which is a source of financing for a company (Fahmi, 2014: 175). The need for funds to strengthen the capital structure of a company can be sourced from internal and external sources, provided that the sources of funds needed are sourced from places that are considered safe and if used have a driving value in strengthening the company's financial capital structure. The theory that underlies the capital structure is the pecking order theory. Pecking order theory explains why profitable companies generally borrow in small amounts Companies that are less profitable will tend to have greater debt for two reasons, namely: (1) insufficient internal funds, and (2) debt is the preferred external source (Husnan, 1996:324). Liquidity is the ability of a company to fulfill its obligations (Rico Andika \& Sedana, 2019). The liquidity ratio can be described in the Current Ratio. Current Ratio describes the comparison between current assets and current liabilities. The greater the company's liquidity ratio, the greater the company's ability to fulfill its obligations. Asset structure is also a factor that affects capital structure. The asset structure describes a portion of the number of assets that can be used as collateral (Putu et al., 2018). The size of the capital structure ratio shows that there are many or less long-term loans than own capital invested in fixed assets that are used to obtain an operating profit.

\section{METHODS}

a. Research Sample

This study uses a quantitative approach, namely research whose analysis focuses more on numerical data (numbers) which are processed using statistical methods. While the population in this study are companies listed on the Indonesia Stock Exchange (IDX) engaged in the consumer goods industry sector for the period 2017-2020 which were taken by purposive sampling, namely the sampling technique with consideration of certain criteria. The data collection technique used in this research is the documentation method, namely by collecting data from reports that have been processed by other parties so that researchers can obtain the required information.

b. Operational Definition and Measurement of Variables

1) Dependent Variable

- Capital structure

The dependent variable in this study is the capital structure. The ratio that can be used to measure capital structure is the Debt to Assets Ratio (DAR). DAR is a debt ratio used to measure the ratio between total debt and total assets. According to (Kasmir, 2015) the formula used is:

$$
\text { DAR }=\frac{\text { Total Amoun Of debt }}{\text { Total Assets }}
$$


2) Independent Variable

- Liquidity

The first independent variable in this study is Liquidity, then symbolized X1. in this study is calculated by the Current ratio. Current ratio is the most commonly used measure to determine the company's ability to meet its short-term obligations from the comparison of current assets with current liabilities. According to (Sutrisno, 2012) the current ratio formula is:

$$
\text { Current Ratio }=\frac{\text { Current asset }}{\text { Current Liability }}
$$

- Asset Structure

The second independent variable is asset structure. Asset structure is the number of assets that can be used as collateral which is measured by comparing fixed assets with total assets. then symbolized by $\mathrm{X} 2$. The formula for the asset structure according to (Weston and Brightman, 2015) is as follows:

Asset Structure $=\frac{\text { Aktiva fixed assets }}{\text { Total Asset }}$

3) Control Variable

The control variable is the variable controlled or made constant so that the relationship of the independent variable to the dependent variable is not influenced by external factors that are not examined. In this study, the control variables are:

- Firm Size

Company size is calculated by the natural log of total assets. The formula for calculating company size is:

$$
\text { Size }=\text { Ln }(\text { Total asset })
$$

c. Data Analysis Techniques

The data obtained during the research process were then analyzed and interpreted to obtain more detailed results. The analysis technique used in this research is as follows:

\subsubsection{Descriptive statistics}

3.3.2 Classic Assumption Test

\subsubsection{Normality Test}

\subsubsection{Multicollinearity Test}

3.3.2.3 Autocorrelation Test

\subsubsection{Heteroscedasticity Test}

3.3.3 Multiple Linear Regression Test

Multiple linear regression test aims to determine the effect of the independent variable on the dependent variable and control variable. The regression equation is as follows:

$$
\begin{gathered}
\mathrm{Y}=\alpha+\beta 1 \mathrm{X} 1+\beta 3 \mathrm{X} 3+\beta 2 \mathrm{X} 2+\beta 3 \mathrm{X} 3+\mathrm{e} \\
\mathrm{Y}=\alpha+\beta 1 \mathrm{X} 1+\beta 2 \mathrm{X} 2+\mathrm{e}
\end{gathered}
$$

Keterangan :

$\begin{array}{ll}\mathrm{Y} & =\text { Capital Structure } \\ \alpha & =\text { Alpha } \\ \beta 1, \beta 2, \beta 3 & =\text { Variable Coefficien }\end{array}$




$\begin{array}{ll}\mathrm{X} 1 & =\text { Liquidity } \\ \mathrm{X} 2 & =\text { Asset Structure } \\ \mathrm{X} 3 & =\text { Firm Size } \\ \mathrm{e} & =\text { Strandard Error }\end{array}$

3.3.4 Simultaneous Test (F)

\subsubsection{Partial Test (T)}

\subsubsection{Coefficient Of Determination Test}

The coefficient of determination can be seen in the Adjusted R Square value which shows how much the independent variable can explain the independent variable. The magnitude of the coefficient of determination is 0 to one. The higher the value of Adjusted R Square, the better the regression model used because it indicates that the ability of the independent variable to explain the dependent variable is also greater, and vice versa.

\section{4) RESULT AND DISCUSSION}

a. Descriptive Statistical Analysis Results

Based on the results of descriptive statistical analysis, table 4.1 will describe the characteristics of the sample used in the study including the number of samples (n), minimum value, maximum value, sample mean (mean) and standard deviation for each variable.

\begin{tabular}{|l|r|r|r|r|r|}
\hline & $\mathrm{N}$ & Minimum & Maximum & Mean & $\begin{array}{c}\text { Std. } \\
\text { Deviation }\end{array}$ \\
\hline Likuiditas & 118 &, 2004 & 5,4879 &, 22736 &, 012729 \\
Struktur_Aset & 118 &, 0407 &, 8051 &, 03745 &, 001614 \\
Struktur_Modal & 118 &, 0507 &, 8430 &, 04145 &, 001706 \\
Ukuran_Perusahaan & 118 & 25,7957 & 32,7256 & 28,9361 &, 016413 \\
Valid N (listwise) & 118 & & & & \\
\hline
\end{tabular}

Table 2. Descriptive Statistical Analysis Results

Source : Output SPSS

1) Liquidity

Liquidity as an independent variable (X1) has a minimum value of 0.2004 and a maximum of 5.4879. The average liquidity is 0.22736 with a standard deviation of 0.012729 .

2) Asset Structure

The asset structure as an independent variable (X2) has a minimum value of 0.0407 and a maximum value of 0.805 . For the average value of 0.03745 with a standard deviation of 0.001614 .

3) Capital Structure

Capital structure as the dependent variable $(\mathrm{Y})$ has a minimum value of 0.0507 and a maximum of 0.8430 . The average capital structure is 0.04145 with a standard deviation of 0.001706 .

4) Firm Size 
Firm size as a control variable (X3) has a minimum value of 25.7957 and a maximum value of 32.7156 . The average company size is 28.9361 with a standard deviation of 0.016413 .

b. Classic Assumption Test Results

- Normality Test Result

The normality test aims to test whether the data is normally distributed or not, by using the One Sample Kolmogorov-Smirnov test method. Here are the results of the normality test:

One-Sample Kolmogorov-Smirnov Test

\begin{tabular}{|ll|r|}
\hline & & Unstandardized Residual \\
\hline $\mathrm{N}$ & Mean & 118 \\
Normal Parameters & a, & .0000000 \\
& Std. Deviation & 1056.71848249 \\
Most Extreme & Absolute & .067 \\
Differences & Positive & .040 \\
Kolmogorov-Smirnov Z & Negative & -067 \\
Asymp. Sig. (2-tailed) & & .730 \\
\hline
\end{tabular}

a. Test distribution is Normal.

b. Calculated from data.

Source :Output SPSS

Table 3. Normality Test Result

Based on the results of the normality test above, it was found that the result of Asymp.sig. (2-tailed) was 0.661 , which means that the result was greater than 0.05 . So it can be said that the research data has been normally distributed and has met the assumption of normality.

- Multicollinearity Test Results

Multicollinearity test aims to test whether the regression model found a correlation between the independent variables (independent). A good regression model should not have a correlation between independent variables (Ghozali, 2018:107). Multicollinearity is seen from the tolerance value and the value of the variance inflation factor (VIF). The following are the results of the multicollinearity test in this study:

Coefficients $^{\mathbf{a}}$

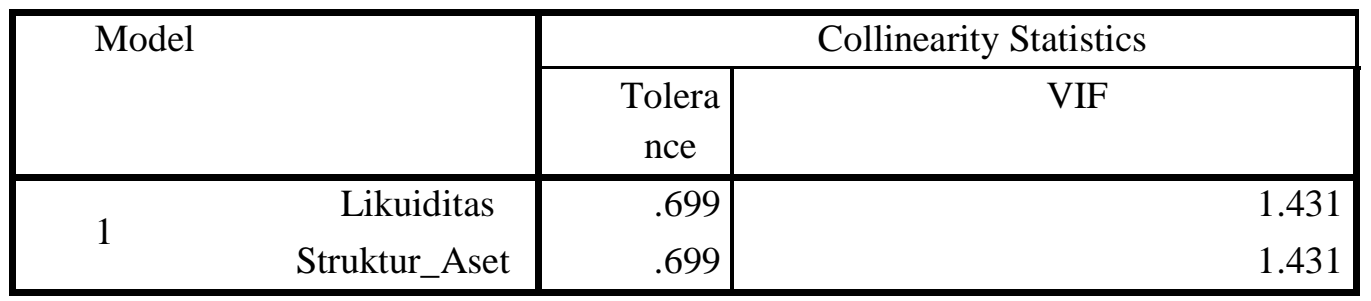

a. Dependent Variable: Struktur_Modal

Source : Output SPSS

Table 4. Multicollinearity Test Results 
The results of the multicollinearity test in table 4.3 above show that all independent variables have a tolerance value above $>0.1$ and a VIF value $<10$, which means that there is no indication of multicollinearity symptoms between independent variables in this study.

\section{- Autocorrelation Test Results}

In this study, the autocorrelation test aims to test whether there is a correlation between the data in the linear regression model. A good regression model is a regression that is free from autocorrelation, if a correlation occurs, it means that there is an autocorrelation problem. To see whether there is autocorrelation in the regression model, it is done by doing the Durbin-Waston test (DW-Test). The following are the results of the autocorrelation test in this study:

\begin{tabular}{|c|c|c|c|c|c|}
\hline \multicolumn{6}{|c|}{ Model Summary ${ }^{b}$} \\
\hline $\begin{array}{l}\text { M } \\
\text { od } \\
\text { el }\end{array}$ & $\mathrm{R}$ & $\begin{array}{c}\mathrm{R} \\
\text { Squar } \\
\mathrm{e}\end{array}$ & $\begin{array}{l}\text { Adjusted } \\
\text { R Square }\end{array}$ & $\begin{array}{l}\text { Std. Error } \\
\text { of the } \\
\text { Estimate }\end{array}$ & $\begin{array}{l}\text { Durbin- } \\
\text { Watson }\end{array}$ \\
\hline 1 & $.785^{\mathrm{a}}$ & .616 & .609 & $\begin{array}{r}1066.8267 \\
043\end{array}$ & 1.953 \\
\hline
\end{tabular}

a. Predictors: (Constant), Struktur_Aset, Likuiditas

b. Dependent Variable: Struktur_Modal

Source : Output SPSS

Table 5. Autocorrelation Test Results

- Heteroscedasticity Test

The heteroscedasticity test is used to test whether or not there is a deviation from the classical assumption of heteroscedasticity, namely the inequality of variance from the residuals between an observation and another observation. The following are the results of the heteroscedasticity test in this study:

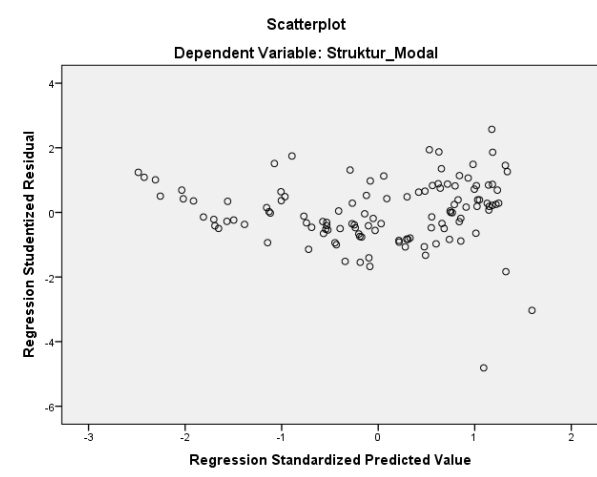

\section{Image 1. Heteroscedasticity Test \\ Source : Output SPSS}

Based on the scatterplot graph above, it can be concluded that the regression model in this study is free from the assumption of heteroscedasticity, which shows that the data points (plots) spread randomly with the distribution of data points above and below the number 0 on the $\mathrm{Y}$ axis. 
c. Multiple Linear Regression Test Results

Multiple linear regression was used to detect the presence or absence of the influence of the independent variable on the dependent variable and the control variable. From this study, the results of multiple linear regression without control variables were obtained as follows:

Coefficients $^{\mathrm{a}}$

\begin{tabular}{|l|r|r|r|r|r|}
\hline \multirow{2}{*}{ Model } & \multicolumn{2}{|c|}{$\begin{array}{c}\text { Unstandardized } \\
\text { Coefficients }\end{array}$} & $\begin{array}{c}\text { Standardized } \\
\text { Coefficients }\end{array}$ & \multirow{2}{*}{ Sig. } \\
\cline { 2 - 4 } & \multicolumn{1}{|c|}{ B } & $\begin{array}{c}\text { Std. } \\
\text { Error }\end{array}$ & Beta & & \\
\hline \multirow{2}{*}{ (Constant) } & 64.01 & 4,38 & & 14.6 & .000 \\
& & & & 00 & .000 \\
Likuiditas & -.103 & .009 & -.771 & - & \\
& & & & 11.1 & \\
Struktur_Aset & .025 & .073 & .024 & .347 & .729 \\
\hline
\end{tabular}

Dependent Variable: Struktur_Modal

Source: Output SPSS

Table 6. Multiple Linear Regression Test Results

Based on the results of the linear regression test in table 4.5 without control variables, the regression equation model can be formed as follows:

$$
\begin{gathered}
\mathrm{Y}=\alpha+\beta 1 \mathrm{X} 1++\beta 2 \mathrm{X} 2+\mathrm{e} \\
\mathrm{Y}=64,10-0,103+0,025+\mathrm{e}
\end{gathered}
$$

The interpretation of the equation is as follows:

1. The constant value $(\alpha)$ in this study is 64,10 which indicates that if there is no increase or decrease in the value of the independent variable. Then the value of the dependent variable is 64, 10.

2. The value of the liquidity coefficient shows a negative direction of -0.103 which means the ability of the capital structure will decrease by -0.0103 .

3. The coefficient value of the asset structure shows a positive direction with the number 0.025 . Which means when the asset structure increases, the capital structure will increase by 0.025 .

The following are the results of multiple linear regression with control variables:

Table 7. Multiple Linear Regression Test Results

\begin{tabular}{|c|c|c|c|c|c|}
\hline \multirow[t]{2}{*}{ Model } & \multicolumn{2}{|c|}{$\begin{array}{l}\text { Unstandardized } \\
\text { Coefficients }\end{array}$} & $\begin{array}{l}\text { Standardized } \\
\text { Coefficients }\end{array}$ & \multirow[t]{2}{*}{$\mathrm{t}$} & \multirow[t]{2}{*}{ Sig. } \\
\hline & B & $\begin{array}{l}\text { Std. } \\
\text { Error }\end{array}$ & Beta & & \\
\hline (Constant) & $\begin{array}{r}55.7 \\
7\end{array}$ & 18.69 & & 2.983 & .003 \\
\hline Likuiditas & .103 & .009 & -.770 & -11.090 & .000 \\
\hline Struktur_Aset & .030 & .074 & .029 & .409 & .683 \\
\hline Ukuran_Perusahaan & .003 & .006 & .027 & .453 & .651 \\
\hline
\end{tabular}

Coefficientsa 
a. Dependent Variable: Struktur_Modal

Source : Output SPSS

The results of table 4.6, the secondary data can be obtained multiple linear regression models as follows:

$$
\begin{gathered}
\mathrm{Y}=\alpha+\beta 1 X 1+\beta 3 X 3+\beta 2 X 2+\beta 3 X 3+\mathrm{e} \\
\mathrm{Y}=55,77-0,103+0,003+0,030+0,003+\mathrm{e}
\end{gathered}
$$

The interpretation of the equation is as follows:

- The constant value $(\alpha)$ in this study is 55.77 which indicates that if there is no increase or decrease in the value of the independent variable. Then the value of the dependent variable is 55.77 .

- The value of the liquidity coefficient shows a negative direction of -0.103 which means the ability of the capital structure will decrease by -0.0103 .

- The value of the coefficient of the asset structure shows a positive direction with the number 0.030 . Which means when the asset structure increases, the capital structure will increase by 0.030 .

- The value of the firm size coefficient shows a positive direction of 0.003 . So when the size of the company increases the capital structure will also increase by 0.003.4.3 Hasil Uji Hipotesis

- Simultaneous Test Results (F Test)

Simultaneous test (F) was conducted to show that all independent variables, namely liquidity and asset structure, had a significant effect on the dependent variable of capital structure together. To make a decision, it is based on the comparison of the value of Fcount with Ftable with a significance level $(\alpha)=5 \%$. Following are the results of the simultaneous test ( $\mathrm{F}$ test):

Table 4.7 Simultaneous Test Results F

ANOVA $^{\mathrm{a}}$

\begin{tabular}{|l|r|r|r|l|l|}
\hline \multicolumn{1}{|c|}{ Model } & $\begin{array}{c}\text { Sum of } \\
\text { Squares }\end{array}$ & df & $\begin{array}{c}\text { Mean } \\
\text { Square }\end{array}$ & F & Sig. \\
\hline $\begin{array}{l}\text { Regression } \\
\text { Residual } \\
\text { Total }\end{array}$ & 209808449.143 & 2 & 04904224.571 & 92.173 & $.000^{\mathrm{b}}$ \\
\hline
\end{tabular}

a. Dependent Variable: Struktur_Modal

b. Predictors: (Constant), Struktur_Aset, Likuiditas

Source : Output SPSS

The value of $F_{\text {count }}$ is $92,173>F_{\text {table }} 3.07$ or with a significance level of 0.000 which is worth $<$ at 0.05 . The significance value $<$ means that $\mathrm{H} 0$ is rejected. Thus the results of this calculation can be taken a decision that the independent variables, namely liquidity, asset structure, simultaneously have a significant effect on the capital structure.

\section{- Partial Test (T Test)}

This partial test $(\mathrm{t})$ is used to test the significance level of the influence of the independent variable liquidity, and the structure of assets on the dependent variable partially. This retrieval is seen from the significance or not of the independent variable on the dependent 
variable in the $t$ test is if the probability value $<0.05$ then it is said to be significant and vice versa.

Tabel 4.8 Partial Test T

Coefficients $^{\mathbf{a}}$

\begin{tabular}{|c|c|c|c|c|c|}
\hline \multirow[t]{2}{*}{ Model } & \multicolumn{2}{|c|}{$\begin{array}{c}\text { Unstandardized } \\
\text { Coefficients }\end{array}$} & $\begin{array}{l}\text { Standardized } \\
\text { Coefficients }\end{array}$ & \multirow[t]{2}{*}{$\mathrm{t}$} & \multirow[t]{2}{*}{ Sig. } \\
\hline & B & Std. Error & Beta & & \\
\hline (Constant) & 6401.150 & 438.431 & & 14.600 & .000 \\
\hline Likuiditas & -.103 & .009 & -.771 & -11.158 & .00 \\
\hline Struktur_Aset & .025 & .073 & .024 & .347 & .729 \\
\hline
\end{tabular}

a.Dependent Variable: Struktur_Modal

Source : Output SPSS

Based on table 4.8 above, it can be concluded that the value of ttable is obtained from $\mathrm{N}$ $\mathrm{K}$, where $\mathrm{N}$ is the number of samples and $\mathrm{K}$ is all the variables in this study. So that $\mathrm{df}=$ $\mathrm{N}-\mathrm{K}=118-3=115$, then the $\mathrm{t}$ table is 1.65821 with a significance value of $5 \%$. So it can be concluded that:

- The significant value of the independent variable liquidity shows 0.000 where this number is smaller than 0.05 . The tcount is -11.158 while the table value is 1.65821 . From these results it can be seen that tcount > Ttable $(-11.090>1.65833)$ so that $\mathrm{H} 1$ is rejected and Ho is accepted. So it can be concluded that partially liquidity has a significant negative effect on capital structure.

- The significant value of the independent variable of asset structure is 0.729 , where this number is greater than 0.05 , which means it is not significant. The tcount is 0.347 while the ttable value is 1.65821 . From these results it can be seen that tcount < Ttable $(0,347$ $>1.65833$ ) so that $\mathrm{H} 1$ is accepted and Ho is rejected. So it can be concluded partially that the asset structure has no significant positive effect on the capital structure.4.5 Hasil Uji Koefisien Determinasi $\left(R^{2}\right)$

The Coefficient of Determination Test is used to determine the percentage contribution of the influence of the independent variable liquidity, asset structure, and firm size control variable on the dependent variable of capital structure. The coefficient of determination value is between zero and one. If in the empirical test, the Adjust R2 value is negative, then the Adjust R2 value is considered zero.

The following is a table of the results of the coefficient of determination in this study:

Table 4.9 Coefficient of Determination Test Results

Model Summary ${ }^{\mathrm{b}}$

\begin{tabular}{|c|r|r|r|r|}
\hline Model & $\mathrm{R}$ & $\begin{array}{c}\mathrm{R} \\
\text { Squa } \\
\mathrm{re}\end{array}$ & $\begin{array}{r}\text { Adjusted } \\
\text { R Square }\end{array}$ & $\begin{array}{c}\text { Std. Error of the } \\
\text { Estimate }\end{array}$ \\
\hline 1 & .78 & .616 & .609 & 1066.8267043 \\
\hline
\end{tabular}

a. Predictors: (Constant), Struktur_Aset, Likuiditas

b.Dependent Variable: Struktur_Modal

Source : Output SPSS 
The results from table 4.9 above show that the dependent variable is influenced by the independent variable with a positive Adjust R Square value of 0.606. This shows that the capital structure is influenced by liquidity, and the asset structure is $60.9 \%$. While the remaining $39.1 \%$ is influenced by other variables outside of this study.

d. Interpretation of Results

- Effect of Liquidity on Capital Structure

Tests in this study indicate that the results of the first hypothesis (H1) are accepted. This means that there is a significant influence between the liquidity variables on the capital structure. Higher liquidity will lower the company's capital structure, which means companies with high liquidity have the ability to pay off their short-term debt, which tends to reduce debt so that the capital structure becomes smaller. Companies with high liquidity have high current assets to finance company activities. Based on the results of this research hypothesis, it is in line with research (Wirawan, 2018) and (Putu et al., 2018) which state that liquidity has a significant effect on capital structure. The results of this study are in accordance with the theoretical basis of Pecking Order Theory, where a company that has a high level of liquidity means that the company has high internal funds. So that a company will tend to use its funds first to finance its investment before using funds from outside parties through debt.

- Effect of Asset Structure on Capital Structure

Based on the results of hypothesis testing, it shows that the independent variable asset structure has no significant effect on capital structure, which means that the second hypothesis (H2) is rejected. This is in line with previous research conducted by (Devi et al., 2017) which states that asset structure has no significant effect on capital structure.

The insignificant result of the effect of asset structure on the company's capital structure is because the sample companies have a low average total assets. Thus the company will have difficulty in obtaining loans from creditors. This is not in accordance with the pecking order theory policy, where the company implements a policy by reducing the ownership of the assets it owns due to sales. Therefore, the asset structure has no significant effect on the capital structure.

- Effect of Liquidity and Asset Structure on Capital Structure with Firm Size as Control Variable

The results of this study are seen from the simultaneous test which states that liquidity, asset structure and company size have a significant effect on capital structure together. Meanwhile, if viewed through a partial test, it states that the asset structure and company size have a positive and insignificant effect on capital structure, while liquidity has a negative and partially significant effect.

The independent variable liquidity has a significance level of 0.000 which means it is smaller than 0.05 which causes liquidity to have a significant effect on the capital structure. Companies that have high liquidity means that they have the ability to pay shortterm debt, so they tend to reduce total debt, which in turn will have a smaller capital structure. The results of this study are in accordance with the theoretical basis, namely the 
pecking order theory which states that companies that have a high level of liquidity also have high internal funds, so they will tend to use their funds first. This is in line with research (Prayogo, 2016) which states that liquidity has a negative and significant effect on capital structure. The independent variable asset structure has a significance value of 0.683 which means it is greater than 0.05 and causes no significant effect on capital structure. The insignificant result of the influence of asset structure on capital structure is because the sample companies have low average total assets. Thus the company will find it difficult to get loans from creditors. This research is supported by research (Devi et al., 2017) which states that asset structure has a positive and insignificant effect on capital structure. Firm size control variable has a significance level of 0.453 . These results indicate that the control variable firm size has no significant effect on capital structure. The results of this study are in line with research (Widyaningrum, 2015) and (Armelia, 2016) which state that company size has no significant effect on capital structure, where large company size will not increase or increase capital structure. This is because several manufacturing companies listed on the Indonesia Stock Exchange, such as the consumer goods industry sub-sector, have determined that most of the profit received is used for company reserves. The results of this study simultaneously show that liquidity and capital structure by using firm size as a control variable have an effect on capital structure. While the results of research partially liquidity has a significant effect on capital structure and asset structure is not significant on capital structure.

\section{5) CONCLUSIONS AND SUGGESTIONS}

a. Conclusions

This study aims to analyze and test whether liquidity, and asset structure affect the capital structure with firm size as a control variable in the consumer goods industrial sector listed on the IDX for the 2017-2020 period. Based on the results of the research above, several conclusions can be obtained as follows:

- The independent variable liquidity has a significant effect on the capital structure, which means that $\mathrm{H} 1$ is accepted.

- The independent variable of asset structure has no significant effect on capital structure, which means $\mathrm{H} 2$ is rejected.

- The firm size control variable has no significant effect on the capital structure, which means that $\mathrm{H} 3$ is rejected.

b. Suggestion

Further research is suggested to add variables that may give more influence to the capital structure. This is in order to improve the test results of the coefficient of the determinant $\mathrm{R}$, thereby knowing other variables that can explain the capital structure with better results. Other variables that may be added are earning volatility, debt service capacity or non-debt tax shields

\section{REFERENCES}

Agung, \& Yuesti, A. (2017). Metodologi Penelitian Kuantitatif dan Kualitatif. 
Yogyakarta:AB Publisher.

Armelia, S. (2016). Pengaruh Ukuran Perusahaan, Profitabilitas, Likuiditas Dan Struktur Aktifa Terhadap Struktur Modal Perusahaan Manufaktur Go Publik. Jurnal Ilmu Komunikasi, 3(2), 1-15.

Devi, N. M. N. C., Sulindawati, N. L. G. E., \& Wahyuni, M. A. (2017). Pengaruh Struktur Aktiva, Profitabilitas, Ukuran Perusahaan, Likuiditas, dan Kepemilikan Manajerial terhadap Struktur Modal Perusahaan (Studi Empiris pada Perusahaan Manufaktur yang Terdaftar di Bursa Efek Indonesia Periode 2013-2015). E-Journal S1 Ak Universitas Pendidikan Ganesha, 7(1), 1-12.

Ghozali, I. (2018). Aplikasi Analisis Multivariete Dengan Program IBM SPSS 23. Semarang:Universitas Diponogoro.

Harina,. (2018). Pengaruh Profitabilitas, Pertumbuhan Penjualan, Struktur Aktiva Danukuran Perusahaan Terhadap Struktur Modal Pada Perusahaan Property Dan Real Estate Yang Terdaftar Di Bursa Efek Indonesia EcoGen. 1, 87-96.

Husnan, S. (1996). Teori Portofolio Dan Analisis Sekuritas.Surakarta:OPAC unisri. Mustanda, I. K. (2018). Likuiditas, Penjualan , Dan Struktur Aset Terhadap Struktur Modal. E-Journal Akuntansi 7(7), 3471-3501.

Luh, N., Ayu, P., \& Sari, Y. (2019). Pengaruh Profitabilitas, Ukuran Perusahaan, Struktur Aktiva, Dan Likuiditas Terhadap Struktur Modal. E-Journal Akuntansi. 568-579.

Masnoon, M., \& Anwar, F. (2012). Capital Structure Determinants of KSE Listed Pharmaceutical Companies. Gmjacs, 2(1), 19-38.

Nelyumna, N. (2018). Faktor-Faktor Yang Mempengaruhi Struktur Modal Pada Perusahaan Manufaktur Yang Go Public. Liquidity, 5(1), 19-26.

Pande, I. M., \& Putra, D. (2019). Pengaruh Profitabilitas, Struktur Aset, Likuiditas, Dan Pertumbuhan Penjualan Terhadap Struktur Modal Perusahaan Makanan Dan Minuman. E-Jurnal Akuntansi 28, 641-668.

Putu, N., Septiani, N., Ngurah, I. G., Suaryana, A., Putu, N., Septiani, N (2018). Pengaruh Profitabilitas, Ukuran Perusahaan, Struktur Aset, Risiko Bisnis dan Likuiditas pada Struktur Modal. ISSN : 2302-8556 E-Jurnal Akuntansi. 22, $1682-1710$.

Rico Andika, I. K., \& Sedana, I. B. P. (2019). Pengaruh Profitabilitas, Struktur Aktiva,

Dan Ukuran Perusahaan Terhadap Struktur Modal. E-Jurnal Manajemen Universitas Udayana, 8(9).

Sujarweni, W. (2015). Metodologi Penelitian Bisnis.Yogyakarta:Graha Ilmu.

Widyaningrum, Y. (2015). Pengaruh Profitabilitas, Struktur Aktiva dan Ukuran Perusahaan Terhadap Struktur Modal. Akuntansi, 151, 10-17.

Wirawan, P. A. (2018). Pengaruh Profitabilitas, Likuiditas, Pertumbuhan Penjualan, dan Struktur Aktiva Pada Struktur Modal. Journal of Chemical Information and Modeling, 53(9), 1689-1699. 